\title{
Epiphytic Survival of Pantoea ananatis on Richardia scabra L. in Georgia
}

\author{
Bhabesh Dutta, Faith Anderson, Samuel Smith, and Ronald D. Gitaitis, Department of Plant Pathology, University of Georgia, Coastal \\ Plain Experiment Station, Tifton 31793-0748
}

\begin{abstract}
Pantoea ananatis, the causal organism of center rot of onion (Allium cepa L.), can survive on different weeds but, in a previous survey, it was most commonly found on Florida pusley (Richardia scabra L.). The epiphytic survival of $P$. ananatis on $R$. scabra under different temperature and moisture regimes was investigated. Weed seedlings were spray inoculated with rifampicin-resistant strain PNA 97-1 $1^{\text {rif }}$ at either $10^{3}$ or $10^{8} \mathrm{CFU} / \mathrm{ml}$ and incubated in a growth chamber at 15.5 or $21.1^{\circ} \mathrm{C}$ at $65 \%$ relative humidity for $96 \mathrm{~h}$ postinoculation (hpi), which represented the mean environmental conditions during mid-March to mid-May in Vidalia, GA when onion production and $R$. scabra presence overlap. For plants inoculated with $P$. ananatis at $10^{3} \mathrm{CFU} / \mathrm{ml}$, the bacterium survived for $96 \mathrm{hpi}$ when incubated at $21.1^{\circ} \mathrm{C}$, with mean populations of $1.7 \times 10^{2} \mathrm{CFU} / \mathrm{g}$ of leaf tissue. In contrast, no viable bacteria

were detected after $72 \mathrm{hpi}$ at $15.5^{\circ} \mathrm{C}$. For plants inoculated with $P$. ananatis at $10^{8} \mathrm{CFU} / \mathrm{ml}$, the bacterium survived for $96 \mathrm{hpi}$ at $21.1^{\circ} \mathrm{C}$ $\left(3.8 \times 10^{5} \mathrm{CFU} / \mathrm{g}\right)$ whereas, during the sample time period, viable bacterial populations were not detected at $15.5^{\circ} \mathrm{C}$. Survival of $P$. ananatis on $R$. scabra was also monitored during alternating $12 \mathrm{~h}$ wet and $12 \mathrm{~h}$ dry periods, or continuous wet or dry periods for $96 \mathrm{hpi}$ at 15.5 or $21.1^{\circ} \mathrm{C}$. Compared with initial or continuous dry periods, $P$. ananatis survived significantly better with a $12 \mathrm{~h}$ wet/ $12 \mathrm{~h}$ dry cycle or a continuous $96 \mathrm{hpi}$ wet period at both 15.5 and $21.1^{\circ} \mathrm{C}$. Unlike at $15.5^{\circ} \mathrm{C}, P$. ananatis populations $\left(7.4 \times 10^{2} \mathrm{CFU} / \mathrm{g}\right)$ survived for $96 \mathrm{hpi}$ at $21.1^{\circ} \mathrm{C}$ under a cycle of $12 \mathrm{~h}$ dry and $12 \mathrm{~h}$ wet. These results demonstrate that $P$. ananatis can survive on $R$. scabra leaves under conditions of $21.1^{\circ} \mathrm{C}$ and prolonged leaf wetness and may potentially serve as a source of inoculum to onion.
\end{abstract}

Center rot of onion (Allium cepa L.) is caused by a gram-negative bacterium, Pantoea ananatis (Serrano) Mergaert. The pathogen was first associated with center rot in Georgia in 1997 on 'Vidalia' onion. Since then, it has been spreading to different onion-growing regions in the United States. The symptoms of center rot start with watersoaking lesions on foliage which run along the length of the leaf. The lesions may gradually turn necrotic and produce a blighted appearance with disease progression. In severe cases, infected plants may wilt and exhibit a bleached appearance of the foliage (Dutta et al. 2014; Gitaitis and Gay 1997). P. ananatis can also invade the bulb tissue and cause bulb discoloration. The bacterial invasion can predispose the bulb to postharvest rot caused by the secondary microbes in storage. Under favorable conditions, yield losses to this disease may be as high as $100 \%$ (Gitaitis and Gay 1997).

Multiple sources of $P$. ananatis inoculum have been associated with center rot epidemics (Dutta et al. 2014; Gitaitis et al. 2002, 2003; Walcott et al. 2002). Infested onion seed can introduce inoculum to onion field. P. ananatis is both seedborne and seed transmitted in onion and, under favorable conditions, the bacterium can cause considerable economic losses (Goszczynska et al. 2006; Walcott et al. 2002). P. ananatis can also be transmitted to onion by two known insect vectors, Frankliniella fusca (tobacco thrips) and Thrips tabaci (onion thrips) (Dutta et al. 2014, 2016; Gitaitis et al. 2003; Wells et al. 2002). The mode of bacterial transmission was reported to be passive through contaminated thrips feces (Dutta et al. 2014, 2016). $P$. ananatis has also been reported to survive as an epiphyte on weeds in the farmscapes of Georgia in the United States (Gitaitis et al. 2002). At least 25 asymptomatic weed species, including Digitaria sanguinalis, Florida beggarweed (Desmodium tortuosum), Florida pusley (Richardia scabra), sicklepod (Cassia obtusifolia), Texas Millet (Panicum texanum), tall verbena (Verbena bonariensis), and yellow nutsedge (Cyperus esculentus), and crop plants such as

Corresponding author: B. Dutta; E-mail: bhabesh@uga.edu

*The $\boldsymbol{e}$-Xtra logo stands for "electronic extra" and indicates that one supplementary table is published online.

Accepted for publication 8 December 2016.

C) 2017 The American Phytopathological Society
Bermuda grass (Cynodon dactylon), cowpea (Vigna unguiculata), and soybean (Glycine max), were reported to harbor epiphytic populations of Pantoea ananatis (Gitaitis et al. 2002). Among these weeds, $P$. ananatis was consistently recovered from $R$. scabra, which is a common weed in and around onion fields in the southeastern United States. Although the epidemiological role of these weeds in center rot epidemics is not clear, it is speculated that they may potentially contribute to the source of $P$. ananatis inoculum in onion field.

$R$. scabra is distributed throughout the onion-growing region of Georgia. This weed is prevalent during the months of March to October in southeastern Georgia and overlaps with onion production only for 3 months (March, April, and May). Interestingly, center rot epidemic reports are more frequent during these months. In preliminary experiments, we demonstrated that transmission of $P$. ananatis can occur from thrips that fed on contaminated $R$. scabra (naturally occurring epiphytic populations) under greenhouse conditions. These observations suggest that contaminated thrips and weeds may play an important role in center rot epidemics. However, factors that involve pathogen survival on weeds, pathogen acquisition from weeds by thrips, and further transmission to onion remain unclear. In this article, we demonstrate $P$. ananatis survival on $R$. scabra under conditions that represented the mean environmental conditions during mid-March to mid-May in Vidalia, GA when onion production and $R$. scabra presence overlap.

\section{Materials and Methods}

Bacterial strains and inoculum preparation. A rifampicinresistant strain of $P$. ananatis (PNA 97- ${ }^{\text {rif }}$ ), generated specifically for this study, was used. This strain was developed from a parent strain of PNA 97-1 (Gitaitis and Gay 1997). The strain PNA 97$1^{\text {rif }}$ was pathogenic on onion and displayed growth in rifampicinamended nutrient broth similar to that of its parent strain (PNA 97-1) in nutrient broth.

The inoculum was prepared by inoculating $3 \mathrm{ml}$ of nutrient broth amended with rifampicin at $100 \mu \mathrm{g} / \mathrm{ml}$, with single colonies of $P$. ananatis taken from 48-h-old antibiotic-amended nutrient agar (NA) plates. The inoculated culture was incubated overnight at $28^{\circ} \mathrm{C}$ on a rotary shaker (Innova; New Brunswick Scientific, Edison, $\mathrm{NJ})$ at $150 \mathrm{rpm}$. After $24 \mathrm{~h}$ of incubation, $3 \mathrm{ml}$ of bacterial suspension was centrifuged at $6,000 \times g$ (AllegraTM 25R; Beckman Coulter, Fullerton, CA) for $5 \mathrm{~min}$, supernatant was discarded, and the resulting pellet was resuspended in $0.1 \mathrm{M}$ phosphate-buffered saline 
solution (PBS). Further, bacterial concentration was adjusted to an optical density of 0.3 at $600 \mathrm{~nm}$ (approximately $1 \times 10^{8} \mathrm{CFU} / \mathrm{ml}$ ) using a spectrophotometer (Spectronic 20; Bausch and Lomb, Rochester, NY). Ten-fold serial dilutions in $0.9 \mathrm{ml}$ of $0.1 \mathrm{M}$ PBS was done to reach a final concentrations of approximately $1 \times 10^{3} \mathrm{CFU} / \mathrm{ml}$. For our study, two inoculum levels were used: $1 \times 10^{8}$ and $1 \times 10^{3}$ $\mathrm{CFU} / \mathrm{ml}$.

Collection of $\boldsymbol{R}$. scabra. In $2015, R$. scabra samples were collected from the perimeter of the onion fields that had significant levels of center rot, or from areas that were left fallow in the current season but had been traditionally used for growing onion in the recent past. The identity of the weeds from which the leaf samples were taken were marked by flags and unique identification numbers for the weed and the sample site were assigned. Both sites were from the Tift County, GA. Leaf samples from weeds ( $n=25 /$ location) were collected from the edge of fields. Samples were collected in plastic bags, stored in an ice cooler, and brought back to the laboratory for processing. In the laboratory, samples were temporarily stored at $4^{\circ} \mathrm{C}$ until they were processed.

Processing of weed samples. Leaf samples $(2 \mathrm{~g})$ were placed in $20 \mathrm{ml}$ of $0.1 \mathrm{M}$ PBS and shaken overnight at approximately $150 \mathrm{rpm}$ on a rotary shaker at $25^{\circ} \mathrm{C}$. After incubation, $1.0 \mathrm{ml}$ of the aliquot was removed and transferred to a $2-\mathrm{ml}$ microcentrifuge tube. Samples were further centrifuged for $5 \mathrm{~min}$ at $5,000 \times g$ (Allegra $25 \mathrm{R})$ and the supernatant was decanted, leaving a pellet that was then resuspended in 0.1 M PBS. Microbial genomic DNA extraction was conducted on the pellet using an UltraClean Microbial DNA Kit (MO BIO, Carlsbad, CA) according to the manufacturer's protocol. DNA samples $(5 \mu \mathrm{l}$ of $1 \mathrm{ng} / \mu \mathrm{l})$ were amplified in $25 \mu \mathrm{l}$ of reaction mix with polymerase chain reaction (PCR) mastermix (Eppendorf Real Master Mix Probe; Eppendorf, Hamburg, Germany or Bio-Rad iQ Supermix; Bio-Rad Laboratories, Hercules, CA), $25 \mu \mathrm{M}$ of each primer PanITS1 (5'-GTCTGATAGAAAGATAAAGAC-3') and EC5 (5'CGGTGGATGCCCTGGCA-3') (Walcott et al. 2002), and $10 \mu \mathrm{M}$ TaqMan probe 6-FAM TAGCGGTTAGGACTCCGCCCTTTCABHQ. DNA amplification was carried out in a Cepheid Smart Cycler (Sunnyvale, CA) using the following thermal profile: denaturation at $95^{\circ} \mathrm{C}$ for $180 \mathrm{~s}$ and 35 cycles each of denaturation at $95^{\circ} \mathrm{C}$ for $15 \mathrm{~s}$ and annealing at $60^{\circ} \mathrm{C}$ for $40 \mathrm{~s}$. Samples with cycle threshold values less than 35 were considered positive for $P$. ananatis (Dutta et al. 2014; Walcott et al. 2002).

The samples that came negative for $P$. ananatis by real-time PCR assay were recorded. Later, sample sites were revisited and the entire plants (for which leaf samples were negative for $P$. ananatis) were uprooted with intact root, brought back to the greenhouse at the University of Georgia, Tifton, and planted in 10-liter plastic pots containing commercial potting mix (Scotts Miracle-Gro Company, Marysville, $\mathrm{OH}$ ).

Effect of temperature on epiphytic survival of $\mathrm{P}$. ananatis on R. scabra. $R$. scabra seedlings or plants ( $n=15$ each for treatment and control) negative for harboring $P$. ananatis as epiphyte were established in 10-liter plastic pots containing commercial potting mix. Pots were spaced evenly on benches in the growth chamber (Controlled Environments Inc., Pembina, ND). Plants were fertilized with Osmocote smart-release plant food (14-14-14) (Scotts MiracleGro Company). Once plants were established, foliage was spray inoculated with a $P$. ananatis suspension containing $10^{3}$ or $10^{8} \mathrm{CFU} / \mathrm{ml}$. The inoculum was sprayed using a hand-trigger sprayer (model 916CN; Contico International, St. Louis) until runoff. Later, plants were incubated under conditions of either 15.5 or $21.1^{\circ} \mathrm{C}$ and $65 \%$ relative humidity $(\mathrm{RH})$ for $96 \mathrm{~h}$ and a photoperiod cycle of $12 \mathrm{~h}$ of light and $12 \mathrm{~h}$ of darkness. The conditions tested in this study represented 12-year (2004 to 2015) mean average temperature and RH for the months of March and May in Vidalia, GA (Supplementary Table S1). The WatchDog Data Logger (model 150; Spectrum Technologies, Aurora, IL) was used to monitor temperature and RH. At each sampling period $(0,6,24,48,72,96 \mathrm{~h}$ post-inoculation [hpi]), three inoculated leaves were arbitrarily sampled, weighed, and processed for $P$. ananatis enumeration as follows. For enumeration, leaf samples were individually placed in $5 \mathrm{ml}$ of $0.1 \mathrm{M}$ PBS and shaken overnight at approximately $150 \mathrm{rpm}$ on a rotary shaker at $25^{\circ} \mathrm{C}$. After incubation, leaf samples were removed and the suspension was transferred to a $15-\mathrm{ml}$ polypropylene tube. Samples were further centrifuged for $5 \mathrm{~min}$ at 5,000 $\times g$ (Allegra 25R) and the supernatant was decanted, leaving a pellet that was then resuspended in $1 \mathrm{ml}$ of $0.1 \mathrm{M}$ PBS. The suspension was vortexed vigorously for $30 \mathrm{~s}$, followed by 10 -fold serial dilutions in $1 \mathrm{ml}$ of PBS. Subsequently, $100-\mu 1$ aliquots were spread plated onto NA plates amended with rifampicin at $100 \mu \mathrm{g} / \mathrm{ml}$ and incubated for $48 \mathrm{~h}$ at $28^{\circ} \mathrm{C}$. After incubation, bacterial colonies were enumerated and recorded from each sampling point. $R$. scabra plants treated with PBS and processed as described above served as a negative control. Two independent experiments were conducted and treatments were arranged in a split-plot design. Area under the growth progress curve (AUGPC) for each replicate per treatment was also calculated as follows: $\sum_{i=1}\left[\left(Y_{i+n 1}+Y_{i}\right)\right] / 2$ $\left[X_{i+1}-X_{i}\right]$, where $Y_{i}=$ bacterial population at the $i$ th observation, $X_{i}=$ time in hours at the $i$ th observation, and $n=$ the total number of observations. Analysis of variance was conducted on the AUGPC values to determine significance of treatment effects on $P$. ananatis populations, and Fischer's least significant difference (LSD) test $(P<0.05)$ was used for mean separation.

Effect of intermittent wet and dry cycle on epiphytic survival of P. ananatis on R. scabra. R. scabra plants confirmed as negative for $P$. ananatis as epiphyte were used for this experiment. Plants were established in a 10-liter pot and spray inoculated with $P$. ananatis at $10^{3} \mathrm{CFU} / \mathrm{ml}$ until runoff, as described above. Later, plants were kept in growth chambers with an incubation temperature of either 15.5 or $21.1^{\circ} \mathrm{C}$, each with the following wetting regimes: continuous wet or dry conditions for $96 \mathrm{hpi}, 12 \mathrm{~h}$ wet alternated with $12 \mathrm{~h}$ dry periods for $96 \mathrm{hpi}$, or $12 \mathrm{~h}$ dry periods alternated with $12 \mathrm{~h}$ wet periods for 96 hpi or continuous wet or continuous dry for 96 hpi. For different wetting regimes, plants were kept in the temperaturecontrolled growth chambers with a humidifier (Trion 707U, Indian Trail, NC), which created high mean RH ( $\geq 94 \%)$. For drying regimes, plants were moved to another temperature-controlled growth chamber with mean $\mathrm{RH}$ of $30 \%$. Based on the duration of wetting and drying cycles, plants from each treatment were moved to temperature- and humidity-controlled growth chambers. Temperature and RH inside the growth chambers were also monitored using data loggers (WatchDog 150; Spectrum Technologies). The plants were maintained under a photoperiod of $12 \mathrm{~h}$ of light and $12 \mathrm{~h}$ of darkness. Three leaf samples per temperature and wetting regime conditions were arbitrarily sampled $(0,6,24,48,72$, and 96 hpi), weighed, and processed for $P$. ananatis enumeration, as described above. $R$. scabra plants treated with PBS and processed as described above served as a negative control. Fifteen plants per treatment were used in a single experiment and two independent experiments were conducted. The treatments were arranged in a split-plot design. Area under the disease progress curve (AUDPC) was calculated for each treatment and compared statistically by Fisher's LSD after confirming the treatment effect using analysis of variance (ANOVA) at the $P<0.05$ level.

Confirmatory tests for $\boldsymbol{P}$. ananatis. Bacterial colonies isolated on NA amended with rifampicin medium were confirmed as $P$. ananatis using specific real-time PCR assays, as described above.

Bacterial colonies were also tested for pathogenicity on onion. For the pathogenicity assay, three randomly selected colonies per plate per $R$. scabra plant were transferred to the nutrient broth and grown overnight at $28^{\circ} \mathrm{C}$ on a rotary shaker (Innova; New Brunswick Scientific) at $150 \mathrm{rpm}$. After $24 \mathrm{~h}$ of incubation, the bacterial suspension was centrifuged at 6,000 $\times g$ (AllegraTM 25R; Beckman Coulter), supernatant was discarded, the resulting pellet was resuspended, and the $P$. ananatis concentration was adjusted to 0.3 at $600 \mathrm{~nm}$ (approximately $1 \times 10^{8} \mathrm{CFU} / \mathrm{ml}$ ) using a spectrophotometer (Spectronic 20; Bausch and Lomb).

Onion seedlings ('Century') were planted in pots of 10 by $8 \mathrm{~cm}$ (diameter by height; Hummert International, Earth City, MO) in a commercial potting mix in the greenhouse and maintained at 25 to $28^{\circ} \mathrm{C}$ and 80 to $90 \% \mathrm{RH}$ with a photoperiod of $12 \mathrm{~h}$ of light and $12 \mathrm{~h}$ of darkness. Mechanical inoculation was done by clipping 
seedlings with a pair of sterile scissors at approximately $5 \mathrm{~cm}$ below the apex. Using a micropipette, four $10-\mu l$ drops (diagonally opposite) of bacterial suspensions containing $P$. ananatis isolates at $1 \times$ $10^{8} \mathrm{CFU} / \mathrm{ml}$ (approximately $1 \times 10^{6} \mathrm{CFU} / \mathrm{ml}$ ) from $R$. scabra were placed at the cut ends of the seedlings. Seedlings mechanically inoculated with PBS as described above were used as negative controls. Three replications per colony per plate per $R$. scabra plant were used in two independent trials. Seedlings were checked visually for symptom development (water-soaked, blighted leaves that gradually turned necrotic) at 3-day intervals for 15 days.

Statistical analysis. $P$. ananatis colony counts were $\log _{10}$ transformed as $\log _{10} \mathrm{CFU} / \mathrm{g}$ of fresh leaf weight. The $\log _{10}$-transformed data of each treatment for both experiments were compared by ANOVA using PROC GLIMMIX (version 9.4; SAS Institute Inc., Cary, NC). The data for two experiments were pooled together after ascertaining that experimental effect was not significant $(P=0.625)$. The effect of main-plot treatment (temperature or wetness regime) was tested against the main-plot error, run-temperature, split-plot treatment, and sampling time, and interactions were tested against the residual error.

\section{Results}

Effect of temperature on epiphytic survival of $P$. ananatis on R. scabra. $R$. scabra plants were inoculated with $10^{3}$ and $10^{8}$ $\mathrm{CFU} / \mathrm{ml}$ separately and incubated for 96 hpi under growth chamber conditions. For R. scabra plants inoculated with $10^{3} \mathrm{CFU} / \mathrm{ml}$, the mean $P$. ananatis populations recovered at 0 hpi from $R$. scabra incubated at 15.5 and $21.1^{\circ} \mathrm{C}$ were $3.8 \times 10^{2}$ and $3.5 \times 10^{2} \mathrm{CFU} / \mathrm{g}$, respectively (Fig. 1A). After $6 \mathrm{hpi}$, bacterial populations decreased to $1.95 \times 10^{1} \mathrm{CFU} / \mathrm{g}$ for plants incubated at $15.5^{\circ} \mathrm{C}$ whereas the mean $P$. ananatis population recovered from plants incubated at $21.1^{\circ} \mathrm{C}$ was $3.9 \times 10^{2} \mathrm{CFU} / \mathrm{g}$. By $24 \mathrm{hpi}$, mean populations recovered from 15.5 and $21.1^{\circ} \mathrm{C}$ treatments were $1.3 \times 10^{1}$ and $4.3 \times 10^{3} \mathrm{CFU} / \mathrm{g}$, respectively (Fig. 1A). The bacterial populations decreased rapidly for $15.5^{\circ} \mathrm{C}$ treatment after $48 \mathrm{hpi}\left(1.05 \times 10^{1} \mathrm{CFU} / \mathrm{g}\right)$ and viable colonies of $P$. ananatis could not be recovered at 72 and 96 hpi. In contrast, although slight decreases in $P$. ananatis populations were observed at 48 hpi $\left(3.8 \times 10^{2} \mathrm{CFU} / \mathrm{g}\right)$ and $72 \mathrm{hpi}\left(5.4 \times 10^{2} \mathrm{CFU} / \mathrm{g}\right)$ for the $21.1^{\circ} \mathrm{C}$ treatment, viable bacterial colonies could still be recovered until $96 \mathrm{hpi}\left(1.7 \times 10^{2} \mathrm{CFU} / \mathrm{g}\right)$ (Fig. 1A). The viable $P$. ananatis populations were not recovered from plants treated with $0.1 \mathrm{M}$ PBS. The AUDPC values for plants incubated at $21.1^{\circ} \mathrm{C}(255.6)$ was significantly higher than the plants incubated at $15.5^{\circ} \mathrm{C}(80.1)(P<0.001)$ (Fig. 1B).

For $R$. scabra plants inoculated with $10^{8} \mathrm{CFU} / \mathrm{ml}$, mean $P$. ananatis populations recovered at $6 \mathrm{hpi}$ for 15.5 and $21.1^{\circ} \mathrm{C}$ treatments were $6.8 \times 10^{7}$ and $7.4 \times 10^{9} \mathrm{CFU} / \mathrm{g}$, respectively. At $24 \mathrm{hpi}$, bacterial populations declined to $1.5 \times 10^{7} \mathrm{CFU} / \mathrm{g}$ for $15.5^{\circ} \mathrm{C}$ treatment whereas $P$. ananatis CFU remained around $1.5 \times 10^{9} \mathrm{CFU} / \mathrm{g}$ for $21.1^{\circ} \mathrm{C}$ treatment (Fig. 1C). By $48 \mathrm{hpi}$, mean populations remained at $2.7 \times 10^{9} \mathrm{CFU} / \mathrm{g}$ for $21.1^{\circ} \mathrm{C}$ whereas it decreased to 2-log order for plants incubated at $15.5^{\circ} \mathrm{C}\left(4.6 \times 10^{5} \mathrm{CFU} / \mathrm{g}\right)$ (Fig. 1C). The bacterial populations decreased rapidly for $15.5^{\circ} \mathrm{C}$ treatment after $72 \mathrm{hpi}$ $\left(1.05 \times 10^{1} \mathrm{CFU} / \mathrm{g}\right)$ and viable colonies of $P$. ananatis could not be recovered by 96 hpi. Although, decline in bacterial populations also
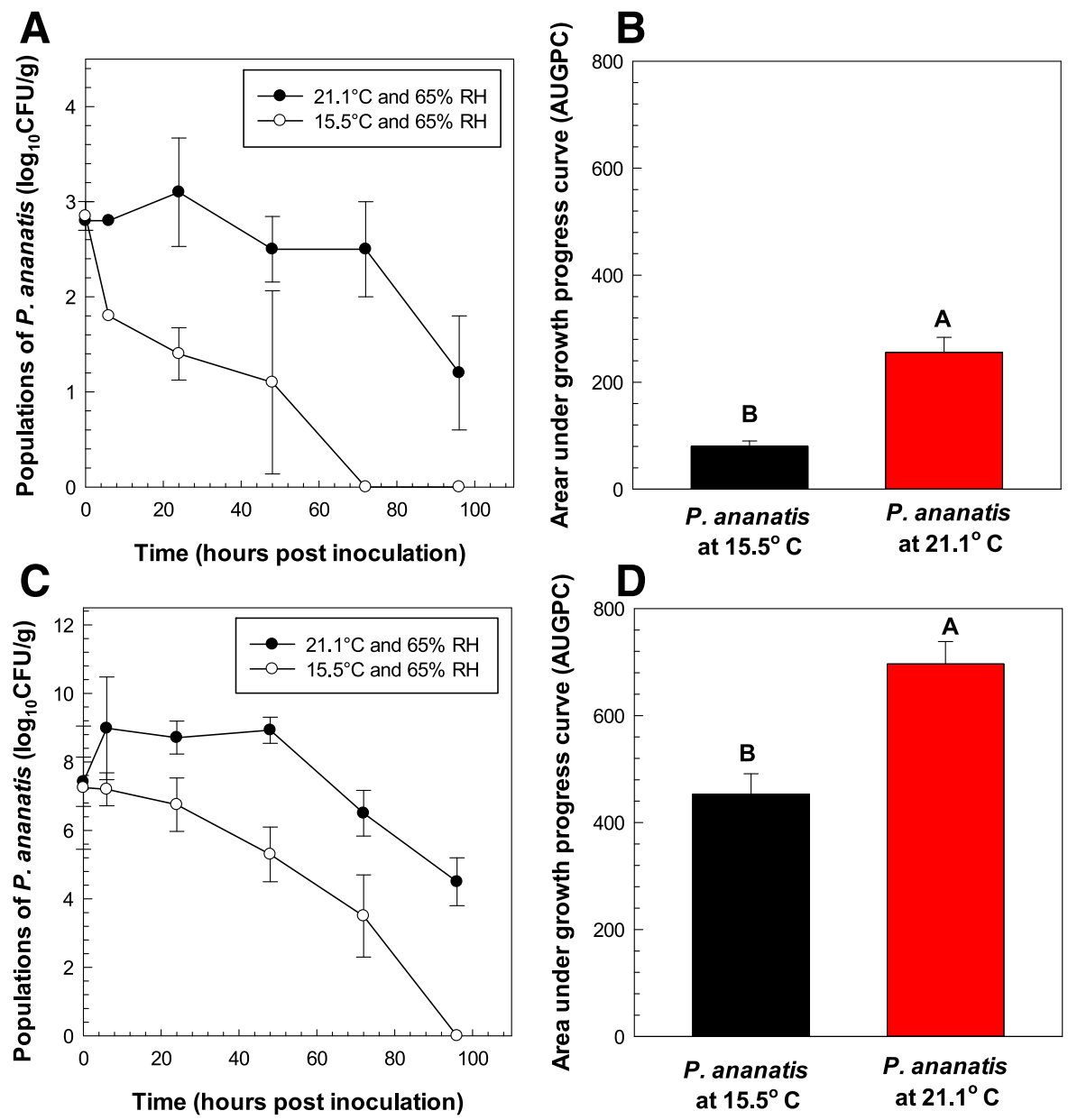

Fig. 1. Epiphytic survival of Pantoea ananatis $97-1^{\text {rif }}$ populations ( $\log _{10} \mathrm{CFU} / \mathrm{g}$ of fresh leaf weight) and area under growth progress curve (AUGPC) on Richardia scabra incubated for $96 \mathrm{~h}$ postinoculation (hpi) under 15.5 and $21.1^{\circ} \mathrm{C}$ and $65 \%$ relative humidity. R. scabra foliage were spray inoculated with $P$. ananatis at either approximately $10^{3} \mathrm{CFU} / \mathrm{ml}$ (A, population counts [CFU/g] and B, AUGPC) or approximately $10^{8} \mathrm{CFU} / \mathrm{ml}$ (C, population counts [CFU/g] and D, AUGPC) and incubated in a growth chamber for $96 \mathrm{~h}$. Three leaf samples per replicate per treatment were sampled at $0,6,24,48,72$, and $96 \mathrm{hpi}$ and populations of $P$. ananatis were enumerated on nutrient agar plates amended with $100 \mu \mathrm{g} / \mathrm{ml}$. Data points represent the mean bacterial populations at each sampling period in two independent experiments. Bars indicate the standard error of the mean. 
occurred at $72 \mathrm{hpi}\left(1.5 \times 10^{6} \mathrm{CFU} / \mathrm{g}\right)$ for $21.1^{\circ} \mathrm{C}$ treatment, high $\mathrm{CFU}$ of $P$. ananatis could still be recovered by $96 \mathrm{hpi}\left(3.8 \times 10^{5} \mathrm{CFU} / \mathrm{g}\right)$ (Fig. 1C). The AUDPC values for plants incubated at $21.1^{\circ} \mathrm{C}$ (696.3) was significantly higher than for plants incubated at $15.5^{\circ} \mathrm{C}$ (453.2) $(P<0.001)$ (Fig. 1D).

Overall, the effect of temperature, sampling period, and inoculum concentrations were significant on $P$. ananatis survival $(P \leq 0.003)$. In addition, significant interactions between temperature-inoculum concentrations, temperature-sampling period, and sampling period-inoculum concentrations on $P$. ananatis CFU were observed $(P \leq 0.001)$ (Table 1).

Effect of intermittent wet and dry cycle on epiphytic survival of P. ananatis on R. scabra. The effect of wet and dry cycles on epiphytic populations of $P$. ananatis was evaluated at 15.5 and $21.1^{\circ} \mathrm{C}$ on $R$. scabra for an initial inoculum level of $10^{3} \mathrm{CFU} / \mathrm{ml}$. At $15.5^{\circ} \mathrm{C}$, mean bacterial populations at $0 \mathrm{hpi}$ for $12 \mathrm{~h}$ wet/12 h dry and $12 \mathrm{~h}$ dry/ $12 \mathrm{~h}$ wet treatments were $8.7 \times 10^{2}$ and $9.05 \times 10^{2} \mathrm{CFU} / \mathrm{g}$, respectively. During the same period, $P$. ananatis populations for continuous wet or continuous dry treatments were $8.7 \times 10^{2}$ and $1.05 \times 10^{3}$ CFU/g, respectively (Fig. 2A). By $24 \mathrm{hpi}$, bacterial populations for treatments with $12 \mathrm{~h}$ wet $/ 12 \mathrm{~h}$ dry and $12 \mathrm{~h}$ dry/12 h wet treatments were $7.5 \times 10^{1}$ and $5.6 \times 10^{2} \mathrm{CFU} / \mathrm{g}$, respectively (Fig. 2A). During the same time period, the treatments continuous wet $\left(9.2 \times 10^{1} \mathrm{CFU} / \mathrm{g}\right)$ or continuous dry $\left(1.8 \times 10^{1} \mathrm{CFU} / \mathrm{g}\right)$ had $1-$ and 2-log order reduction in $P$. ananatis populations, respectively (Fig. 2A). By 48 and

Table 1. Summary of analysis of variance of epiphytic populations of Pantoea ananatis on Richardia scabra foliage at 15.5 and $21.1^{\circ} \mathrm{C}^{\mathrm{a}}$

\begin{tabular}{|c|c|c|c|c|}
\hline Survival, source & $\mathbf{d f}^{\mathbf{b}}$ & Error $^{c}$ & $F$ value & $P>F$ \\
\hline Experiment $^{\mathrm{d}}$ & 1 & Experiment $\times$ temperature & 6.67 & 0.762 \\
\hline Temperature & 1 & Experiment $\times$ temperature & 28.34 & 0.0034 \\
\hline Sampling period $(\text { Sampling })^{\mathrm{f}}$ & 5 & Residual error & 267.28 & 0.0021 \\
\hline Inoculum concentrations (Inoculum) & 1 & Residual error & 15.62 & $<0.001$ \\
\hline Temperature $\times$ Sampling & 5 & Residual error & 31.52 & $<0.001$ \\
\hline Temperature $\times$ Inoculum & 1 & Residual error & 45.52 & $<0.001$ \\
\hline Inoculum $\times$ Sampling & 5 & Residual error & 18.2 & $<0.001$ \\
\hline
\end{tabular}

${ }^{a}$ Mean square error with residual error value was $13.8 \pm 0.52$ for survival at 15.5 and $21.1^{\circ} \mathrm{C}$.

${ }^{\mathrm{b}}$ Degrees of freedom.

${ }^{\mathrm{c}}$ Error term used to test number of the experiment multiplied by temperature treatment.

${ }^{\mathrm{d}}$ Number of experiments.

e Temperature in growth chambers.

${ }^{\mathrm{f}}$ Sampling period of leaves after inoculation.
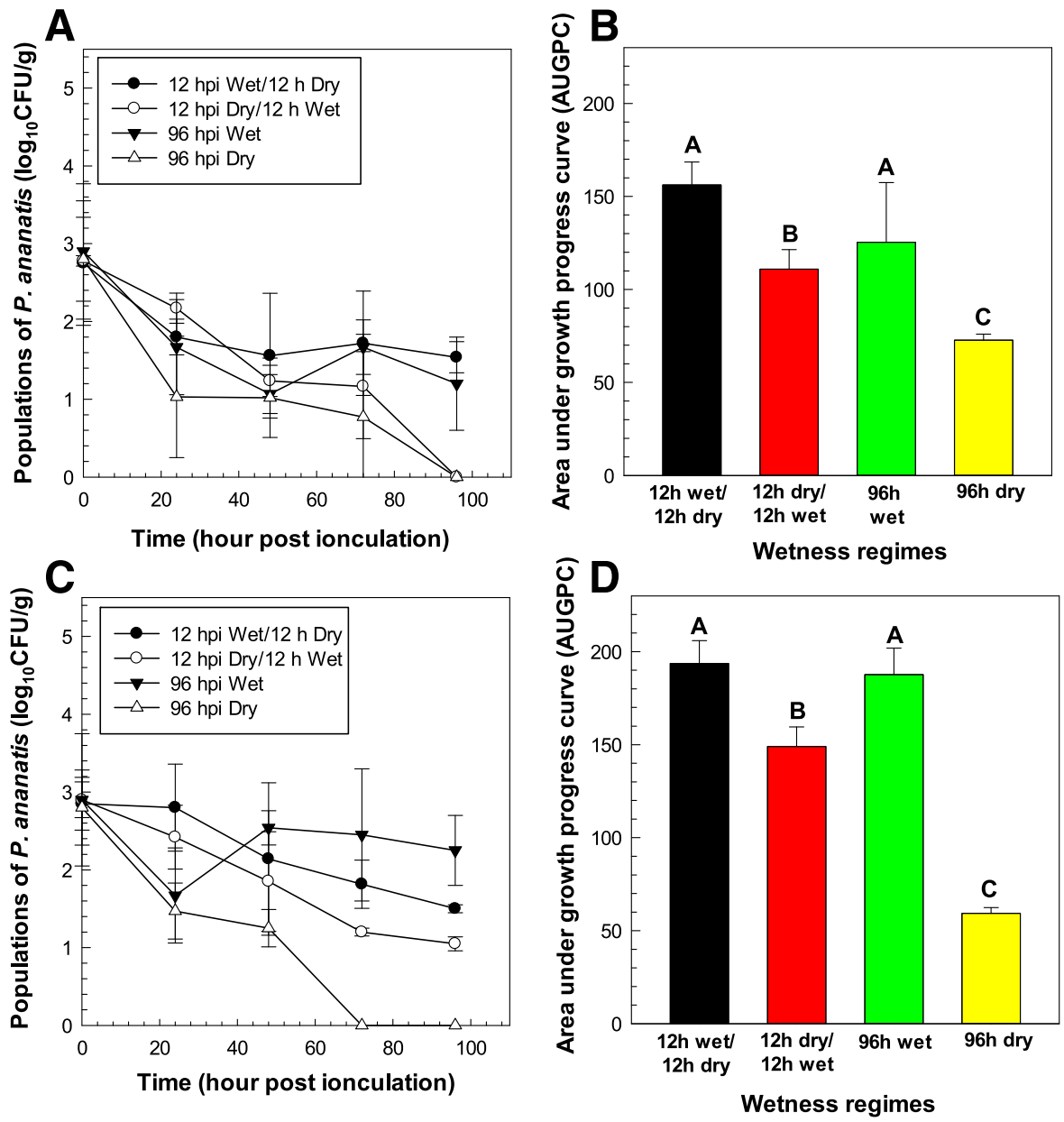

Fig. 2. Epiphytic survival of Pantoea ananatis $97-1^{\text {rif }}$ populations ( $\log _{10} \mathrm{CFU} / \mathrm{g}$ ), with population counts at $\mathrm{A}, 15.5$ and $\mathbf{C}, 21.1^{\circ} \mathrm{C}$, and area under growth progress curve $(\mathrm{AUGPC})$ at B, 15.5 and $\mathbf{D}, 21.1^{\circ} \mathrm{C}$, on Richardia scabra incubated for $96 \mathrm{~h}$ postinoculation (hpi) at 15.5 and $21.1^{\circ} \mathrm{C}$ under different moisture regimes. $R$. scabra plants were spray inoculated with $P$. ananatis at approximately $10^{3} \mathrm{CFU} / \mathrm{ml}$ and incubated at four moisture regimes ( $12 \mathrm{~h}$ wet $12 \mathrm{~h} \mathrm{dry}, 12 \mathrm{~h} \mathrm{dry} / 12 \mathrm{~h}$ wet, continuous wet, or continuous dry) for $96 \mathrm{hpi}$. Three leaf samples per replicate per treatment were sampled at $0,6,24,48,72$, and $96 \mathrm{hpi}$ and populations of $P$. ananatis were enumerated on nutrient agar plates amended with $100 \mu \mathrm{g} / \mathrm{ml}$. Data points represent the mean bacterial populations at each sampling period in two independent experiments. Bars indicate the standard error of the mean. 
$72 \mathrm{hpi}$, $P$. ananatis CFU could be recovered for $12 \mathrm{~h}$ wet/ $12 \mathrm{~h}$ dry (48 hpi: $8.4 \times 10^{1} \mathrm{CFU} / \mathrm{g}$; $72 \mathrm{hpi}: 9.8 \times 10^{1} \mathrm{CFU} / \mathrm{g}$ ) and $12 \mathrm{~h}$ dry $/ 12 \mathrm{~h}$ wet treatments (48 hpi: $2.4 \times 10^{1} \mathrm{CFU} / \mathrm{g} ; 72 \mathrm{hpi}: 1.6 \times 10^{1} \mathrm{CFU} / \mathrm{g}$ ) treatments. During the same sampling periods (48 and $72 \mathrm{hpi}$ ), mean bacterial populations declined for continuous wet (48 hpi: $\left.1.3 \times 10^{1} \mathrm{CFU} / \mathrm{g} ; 72 \mathrm{hpi}: 1.86 \times 10^{1} \mathrm{CFU} / \mathrm{g}\right)$ and continuous dry (48 hpi: $1.2 \times 10^{1} \mathrm{CFU} / \mathrm{g}$; $72 \mathrm{hpi}: 0.8 \times 10^{1} \mathrm{CFU} / \mathrm{g}$ ) treatments (Fig. 2A). At 96 hpi, mean P. ananatis populations for the $12 \mathrm{~h}$ wet/12 h dry treatment was $6.8 \times 10^{1} \mathrm{CFU} / \mathrm{g}$, whereas viable $\mathrm{CFU}$ could not be recovered for $12 \mathrm{~h}$ dry/ $/ 2 \mathrm{~h}$ wet treatment. During the same period, treatment with the continuous wet regime produced $P$. ananatis populations of $1.6 \times 10^{1} \mathrm{CFU} / \mathrm{g}$, whereas bacterial CFU were not recovered for the continuous dry treatment. The AUGPC value for continuous dry (72.7) treatments was significantly lower than other treatments (Fig. 2B). The $12 \mathrm{~h}$ wet/12 h dry (156.2) and continuous wet (125.4) treatments had significantly higher AUGPC values than the $12 \mathrm{~h}$ dry/12 $\mathrm{h}$ wet (110.8) treatment (Fig. 2B).

At $21.1^{\circ} \mathrm{C}$, mean bacterial populations at 0 hpi for $12 \mathrm{~h}$ wet/ $12 \mathrm{~h}$ dry or $12 \mathrm{~h}$ dry/12 h wet or continuous wet or continuous dry treatments were approximately $10^{2} \mathrm{CFU} / \mathrm{g}$. By $24 \mathrm{hpi}$, bacterial CFU declined for treatments with $12 \mathrm{~h}$ wet/ $12 \mathrm{~h}$ dry $\left(6.8 \times 10^{2} \mathrm{CFU} / \mathrm{g}\right)$ and $12 \mathrm{~h}$ dry/12 h wet $\left(3.5 \times 10^{2} \mathrm{CFU} / \mathrm{g}\right)$ regimes (Fig. $\left.2 \mathrm{C}\right)$. The continuous wet $\left(1.5 \times 10^{1} \mathrm{CFU} / \mathrm{g}\right)$ or continuous dry $\left(1.3 \times 10^{1} \mathrm{CFU} / \mathrm{g}\right)$ treatments declined rapidly to the order of 2-log by $24 \mathrm{hpi}$ (Fig. 2C). By 48 and $72 \mathrm{hpi}, P$. ananatis $\mathrm{CFU}$ could be recovered for $12 \mathrm{~h}$ wet/12 h dry (48 hpi: $2.6 \times 10^{2} \mathrm{CFU} / \mathrm{g} ; 72 \mathrm{hpi}: 6.8 \times 10^{1}$ $\mathrm{CFU} / \mathrm{g}$ ) and $12 \mathrm{~h}$ dry/12 h wet (48 hpi: $2.4 \times 10^{1} \mathrm{CFU} / \mathrm{g}$; 72 hpi: $1.6 \times 10^{1} \mathrm{CFU} / \mathrm{g}$ ) treatments. Mean bacterial populations for the continuous dry treatment declined rapidly (48 hpi: $1.2 \times$ $10^{1} \mathrm{CFU} / \mathrm{g}$ ) and viable CFU could not be recovered at 72 and 96 hpi. In contrast, mean $P$. ananatis populations for the continuous wet treatment remained around $2.4 \times 10^{1} \mathrm{CFU} / \mathrm{g}$ (48 hpi) and $1.6 \times 10^{1} \mathrm{CFU} / \mathrm{g}(72 \mathrm{hpi})$ and, by $96 \mathrm{hpi}$, mean CFU recovered was $4.8 \times 10^{2} \mathrm{CFU} / \mathrm{g}$. Also, by $96 \mathrm{hpi}$, mean $P$. ananatis populations for $12 \mathrm{~h}$ wet/12 h dry and $12 \mathrm{~h}$ dry/12 h wet treatments were $7.4 \times$ $10^{2}$ and $1.8 \times 10^{2} \mathrm{CFU} / \mathrm{g}$, respectively.

The AUGPC value for the $24 \mathrm{~h}$ dry treatment (59.4) was significantly lower than other treatments. The treatments with $12 \mathrm{~h}$ wet/ $12 \mathrm{~h}$ dry (193.4) and continuous wet (186.6) had significantly higher AUGPC values than the $12 \mathrm{~h}$ dry/12 h wet treatment (149.2) (Fig. $2 \mathrm{D})$. The viable $P$. ananatis populations were not recovered from plants treated with $0.1 \mathrm{M}$ PBS and incubated at above temperature under wet and dry regimes. Overall, the effects of temperature, sampling period, and treatments were significant on $P$. ananatis survival $(P \leq 0.021$; Table 2). In addition, significant interactions between treatment-sampling period, treatment-temperature, and temperature-sampling period on $P$. ananatis CFU were observed $(P \leq 0.001$; Table 2).

Confirmatory tests for $\boldsymbol{P}$. ananatis. Confirmation of presumptive $P$. ananatis colonies was conducted by a $P$. ananatis-specific realtime PCR assay, as described above. Of the colonies tested, 100\% were amplified using this primer. In addition, $100 \%$ of the onion seedlings displayed center rot symptoms under greenhouse conditions when inoculated with the $P$. ananatis-suspected colonies.

\section{Discussion}

The knowledge of factors affecting pathogen survival on a weed host is critical to understanding the epidemiology of bacterial dispersal and spread from weeds to host crops. The survival of $P$. ananatis on $R$. scabra (a well-known epiphytic host) was investigated under different temperature and moisture regimes. The conditions investigated in this research mimicked the mean temperature and RH during the months of March, April, and May in the Vidalia onion region of southeastern Georgia. During these months, overlapping of $R$. scabra and onion can be observed in this region. Such overlapping may potentially result in the risk of $P$. ananatis spread in onion crop via thrips or wind-driven rain.

According to earlier reports, epiphytic bacteria on leaf surfaces followed a log-normal distribution. Such distribution indicates that, in a subsample of infested or positive leaves, few samples may possess higher bacterial populations $\left(10^{6}\right.$ to $\left.10^{8} \mathrm{CFU} / \mathrm{g}\right)$ whereas the majority of the leaf samples may harbor bacterial populations around $10^{2}$ to $10^{3} \mathrm{CFU} / \mathrm{g}$ (Hirano et al. 1982). Hence, in this study, we investigated $P$. ananatis survival at two levels of initial inoculum $-10^{3}$ (low) and $10^{8}$ (high) CFU—representing two spectra of epiphytic populations in nature. The low inoculum level was used to mimic mean epiphytic populations that generally occur under natural conditions (Beattie and Lindow 1995, 1999; Hirano et al. 1982). In contrast, the high inoculum level represented a worst-case scenario where high bacterial populations could be present in fewer $R$. scabra leaves. The results indicated that, when $R$. scabra leaves were inoculated with $P$. ananatis at $10^{3} \mathrm{CFU} / \mathrm{ml}$, the bacterium could survive to a population level of $1.05 \times 10^{1} \mathrm{CFU} / \mathrm{g}$ at $15.5^{\circ} \mathrm{C}$ for up to $48 \mathrm{~h}$ but could not be recovered at 72 and 96 hpi. In contrast, $P$. ananatis did survive for $96 \mathrm{hpi}$ with a population level of $1.7 \times 10^{2} \mathrm{CFU} / \mathrm{g}$ at $21.1^{\circ} \mathrm{C}$. In addition, AUDPC values were significantly higher for plants incubated at $21.1^{\circ} \mathrm{C}(255.6)$ than for plants incubated at $15.5^{\circ} \mathrm{C}(80.1)$. These observations suggest that, even at low initial $P$. ananatis populations, the bacterium could survive efficiently on $R$. scabra for a longer period of time (96 hpi) when incubated at 21.1 than at $15.5^{\circ} \mathrm{C}$. Similar observations of reduced $P$. ananatis survival on $R$. scabra at 21.1 than at $15.5^{\circ} \mathrm{C}$ was also noted at a higher initial inoculum level $\left(10^{8} \mathrm{CFU} / \mathrm{ml}\right)$. Despite high initial inoculum, $P$. ananatis populations at $15.5^{\circ} \mathrm{C}$ reduced to $0 \mathrm{CFU} / \mathrm{g}$ by $96 \mathrm{hpi}$. In contrast, during the same time period $(96 \mathrm{hpi}), P$. ananatis populations survived $\left(3.8 \times 10^{5} \mathrm{CFU} / \mathrm{g}\right)$ at $21.1^{\circ} \mathrm{C}$. The observations made in this study were in contrast to observations made on epiphytic survival of Erwinia trachiephila (causal agent of bacterial wilt of cucurbit) (Saalau Rojas and Gleason 2012). The researchers reported that E. trachiephila survived longer (48 hpi) and to a higher population when cucumber seedlings were incubated at 10 and $20^{\circ} \mathrm{C}$ than at 30 and $35^{\circ} \mathrm{C}$ (Saalau Rojas and Gleason 2012). Also, in other studies, epiphytic bacterial survival was reduced with an increase in temperature (Beattie and Lindow 1994, 1999). However, in our study, P. ananatis survived comparatively better at 21.1 than at $15.5^{\circ} \mathrm{C}$. It is possible

Table 2. Summary of analysis of variance of epiphytic populations of Pantoea ananatis on Richardia scabra foliage under different wet and dry regimes ${ }^{\mathrm{a}}$

\begin{tabular}{|c|c|c|c|c|}
\hline Survival, source & $\mathbf{d f}^{\mathbf{b}}$ & Error $^{\mathrm{c}}$ & $F$ value & $P>F$ \\
\hline Experiment ${ }^{\mathrm{d}}$ & 1 & Experiment $\times$ treatment & 3.82 & 0.284 \\
\hline Treatment $^{\mathrm{e}}$ & 3 & Experiment $\times$ treatment & 32.51 & 0.0214 \\
\hline Temperature & 1 & Experiment $\times$ temperature & 42.8 & 0.015 \\
\hline Sampling period ${ }^{\mathrm{f}}$ & 4 & Residual error & 253.52 & 0.0072 \\
\hline Treatment $\times$ sampling period & 12 & Residual error & 24.31 & $<0.001$ \\
\hline Treatment $\times$ temperature & 3 & Residual error & 23.7 & $<0.001$ \\
\hline Sampling period $\times$ temperature & 4 & Residual error & 244.28 & $<0.001$ \\
\hline
\end{tabular}

a Mean square error with residual error value was $1.62 \pm 0.17$ for survival under different wet and dry regimes.

${ }^{\mathrm{b}}$ Degrees of freedom.

${ }^{c}$ Error term used to test number of the experiment multiplied by treatments.

d Number of experiments.

e Wet and dry regimes in growth chambers.

${ }^{\mathrm{f}}$ Sampling period of leaves after inoculation. 
that the upper limit $\left(21.1^{\circ} \mathrm{C}\right)$ of temperature tested could certainly fall within temperature optima for $P$. ananatis survival on biological surfaces, which could partly explain why the bacterium survived better at $21.1^{\circ} \mathrm{C}$.

In order to mimic variabilities of alternating moisture regimes (rainfall or overhead irrigation followed by a dry spell or vice versa) under field conditions, $P$. ananatis survival was also evaluated at $12 \mathrm{~h}$ wet/12 h dry or $12 \mathrm{~h}$ dry/12 h wet or continuous wet or continuous dry conditions for $96 \mathrm{hpi}$. These moisture regimes were evaluated at both 15.5 and $21.1^{\circ} \mathrm{C}$ with an initial inoculum population of $10^{3}$ $\mathrm{CFU} / \mathrm{ml}$. At $15.5^{\circ} \mathrm{C}, P$. ananatis survived for $96 \mathrm{hpi}$ with populations of $6.8 \times 10^{1}$ and $1.6 \times 10^{1} \mathrm{CFU} / \mathrm{g}$ in $12 \mathrm{~h}$ wet/ $12 \mathrm{~h}$ dry and continuous wet regimes, respectively, whereas, during the same time period, viable bacterial populations could not be recovered for $12 \mathrm{~h}$ dry/12 h wet or continuous dry regimes. In contrast, at $21.1^{\circ} \mathrm{C}$, bacterial populations survived for $96 \mathrm{hpi}$ under $12 \mathrm{~h}$ wet/ $12 \mathrm{~h}$ dry, $12 \mathrm{~h}$ dry/12 h wet, or continuous wet regimes but $P$. ananatis populations could not be recovered from a continuous dry regime for $96 \mathrm{hpi}$. These observations indicate that $P$. ananatis can survive on $R$. scabra leaves under conditions of $21.1^{\circ} \mathrm{C}$ and prolonged leaf wetness. Moreover, the survival was significantly better at 21.1 than at $15.5^{\circ} \mathrm{C}$ under different moisture regimes. Even under alternating dry or continuous dry conditions, $P$. ananatis survived for $72 \mathrm{hpi}$, indicating that the bacterium could survive stress for a shorter duration. The possible explanation for this phenomenon could be due to selection of a population that can tolerate stress (Beattie and Lindow 1999), or perhaps $P$. ananatis survived in microsites on the leaf surface, thus helping bacterial populations to evade environmental stress (Beattie and Lindow 1995).

Although the epidemiological significance of R. scabra is not well determined, our preliminary investigations indicate that it can potentially act as a link between thrips and onion. Our preliminary investigations under greenhouse conditions showed that $F$. fusca thrips could efficiently acquire epiphytic $P$. ananatis populations from $R$. scabra and were able to transmit the bacterium to onion seedlings, resulting in center rot (data not shown). These data indicate that $R$. scabra can act as a reservoir for epiphytic populations of $P$. ananatis and may serve as an important link in center rot epidemic. A better understanding of the environmental factors that may affect $P$. ananatis survival on $R$. scabra and subsequent spread to an onion crop may potentially improve center rot management.

Overall, for the first time, it was demonstrated that $P$. ananatis can survive as an epiphyte on $R$. scabra under different temperature and moisture regimes that mimicked conditions for the months of March,
April, and May in the Vidalia onion region of Georgia. The results suggest that $P$. ananatis can survive on $R$. scabra leaves under conditions of $21.1^{\circ} \mathrm{C}$ and prolonged leaf wetness and can potentially serve as a source of inoculum to onion. However, the role of weeds in the epidemiology of $P$. ananatis is still not well understood. Perhaps detailed investigations on the role of epiphytic survival of $P$. ananatis and subsequent spread to onion crops may provide necessary information for center rot management. Future studies with more $P$. ananatis strains under a wider range of environmental conditions combined with genetic factors affecting epiphytic survival of $P$. ananatis may provide important clues for bacterial survival.

\section{Literature Cited}

Beattie, G. A., and Lindow, S. E. 1994. Comparison of the behavior of epiphytic fitness mutants of Pseudomonas syringae under controlled and field conditions. Appl. Environ. Microbiol. 60:3799-3808.

Beattie, G. A., and Lindow, S. E. 1995. The secret life of foliar bacterial pathogens on leaves. Annu. Rev. Phytopathol. 33:145-172.

Beattie, G. A., and Lindow, S. E. 1999. Bacterial colonization of leaves: A spectrum of strategies. Phytopathology 89:353-359.

Dutta, B., Barman, A. K., Srinivasan, R., Avci, U., Ullman, D. E., Langston, D. B. and Gitaitis, R. D. 2014. Transmission of Pantoea ananatis and Pantoea agglomerans, causal agents of center rot of onion (Allium cepa L.), by onion thrips (Thrips tabaci Lindeman) through feces. Phytopathology 104:812-819.

Dutta, B., Gitaitis, R., Barman, A., Avci, U., Marasigan, K., and Srinivasan, R. 2016. Interactions between Frankliniella fusca and Pantoea ananatis in the center rot epidemic of onion (Allium cepa). Phytopathology 106:956-962.

Gitaitis, R., Walcott, R., Culpepper, S., Sanders, H., Zolobowska, L., and Langston, D. 2002. Recovery of Pantoea ananatis, causal agent of center rot of onion, from weeds and crops in Georgia, USA. Crop Prot. 21:983-989.

Gitaitis, R. D., and Gay, J. D. 1997. First report of a leaf blight, seed stalk rot, and bulb decay of onion by Pantoea ananas in Georgia. Plant Dis. 81:1096.

Gitaitis, R. D., Walcott, R. R., Wells, M. L., Diaz Perez, J. C., and Sanders, F. H. 2003. Transmission of Pantoea ananatis, causal agent of center rot of onion, by tobacco thrips, Frankliniella fusca. Plant Dis. 87:675-678.

Goszczynska, T., Venter, S. N., and Coutinho, T. A. 2006. PA-20, a semi-selective medium for isolation and enumeration of Pantoea ananatis. J. Microbiol. Methods 64:225-231.

Hirano, S. S., Nordheim, E. V., Amy, D. C., and Upper, C. D. 1982. Lognormal distribution of epiphytic bacterial populations on leaf surfaces. Appl. Environ. Microbiol. 44:695-700.

Saalau Rojas, E., and Gleason, M. L. 2012. Epiphytic survival of Erwinia tracheiphila on muskmelon (Cucumis melo L.). Plant Dis. 96:62-66.

Walcott, R. R., Gitaitis, R. D., Castro, A. C., Sanders, F. H., Jr., and Diaz-Perez, J. C. 2002. Natural infestation of onion seed by Pantoea ananatis, causal agent of center rot. Plant Dis. 86:106-111.

Wells, M. L., Gitaitis, R. D., and Sanders, F. H. 2002. The Association of tobacco thrips. Frankliniella fusca, (Thysanoptera: Thripidae) with two species of bacteria of the genus Pantoea. Ann. Entomol. Soc. Am. 95:719-723. 